\title{
Synchronous collagenous sprue and enteropathy-type $T$ cell lymphoma: Variants of the same disease
}

\author{
SAC Medlicott MD ${ }^{1}, \mathrm{PL}$ Beck PhD MD², S Loken MD ${ }^{1}, \mathrm{~T}$ Crabtree MD ${ }^{1}$
}

\begin{abstract}
SAC Medlicott, PL Beck, S Loken, T Crabtree. Synchronous collagenous sprue and enteropathy-type $\mathrm{T}$ cell lymphoma: Variants of the same disease. Can J Gastroenterol 2004;18(5):329-332.

A 64-year-old man with treated hypothyroidism had 10 months of diarrhea, abdominal pain, anorexia and recent involuntary $13.6 \mathrm{~kg}$ weight loss. He presented to hospital with an acute abdomen that had a radiological correlate of free air under the diaphragm. He was diagnosed with a perforated mid-jejunum due to an ulcerated enteropathy-type T cell lymphoma (ETL), complicating collagenous sprue and cryptic celiac disease. Polymerase chain reaction verified monoclonal $\gamma$ - and $\beta-T$ cell receptor gene rearrangements in the neoplasm. He had a complete resolution of symptoms when treated with a gluten-free diet in the postoperative period.

This is apparently the first report describing collagenous sprue and ETL as synchronous lesions. Because atypical CD8+ lymphocytes are in both the collagenous sprue epithelium and ETL, the implication is that collagenous sprue is a noninvasive component of the ETL.
\end{abstract}

Key Words: Celiac sprue; Collagenous sprue; Enteropathy-type $\mathrm{T}$ cell lymphoma

\section{La sprue collagène synchrone et le lymphome $\mathrm{T}$ à variante entéropathique : Des variantes de la même maladie}

Un homme de 64 ans traité pour hypothyroïdie présentait, depuis dix mois, des diarrhées, des douleurs abdominales, une anorexie et une perte involontaire de 13,6 kg. Il est arrivé à l'hôpital avec une urgence abdominale qui, à la radiographie, corrélait la présence d'air libre sous le diaphragme. On a posé un diagnostic de perforation du jéjunum moyen causée par un lymphome T ulcéré à variante entéropathique (LTVE), une sprue collagène synchrone compliquée et une maladie cœliaque larvée. Une réaction en chaîne de la polymérase a permis de vérifier les réarrangements du gène récepteur des lymphomes $T \gamma$ et $\beta$ dans le néoplasme. Le patient a bénéficié d'une résolution totale des symptômes après un traitement à un régime sans gluten au cours de la période postopératoire.

C'est apparemment le premier compte rendu décrivant une sprue collagène et une LTVE sous forme de lésions synchrones. Puisque les lymphocytes CD8+ se trouvent à la fois dans l'épithélium de la sprue collagène et la LTVE, la sprue collagène serait un élément non envahissant de la LTVE. prerequisite for the diagnosis of celiac sprue is a mucosal
intraepithelial lymphocytosis. The constituent cells of intraepithelial lymphocytes (IEL) are predominantly cytotoxic $\mathrm{T}$ cells that express surface CD4, CD8 and T cell receptor (TCR)- $\beta$ (1). An intraepithelial lymphocytosis can also be the histological correlate of refractory sprue $(1,2)$. Such clinically unresponsive disease may also be associated with thickened superficial basement membranes (collagenous sprue) or ulceration (ulcerative jejunitis).

Classic histology of refractory sprue is a nontumourous intraepithelial lymphocytosis whose constituent cells are usually deemed cytologically bland $(1,2)$. However, this entity often has a CD3+, CD8- IEL phenotype and a monoclonal TCR gene rearrangement (2-5). As such, variants of refractory sprue are now regarded as neoplasia (1-3). Whether collagenous sprue is a monoclonal and/or neoplastic entity is uncertain due to conflicting reports $(3,4)$.

Enteropathy-type T cell lymphoma (ETL) complicating established refractory sprue is well documented and most instances of refractory sprue are now considered cryptic ETL $(1-3,6)$. However, de novo collagenous sprue and ETL have never been recognized as synchronous entities. Herein, a case of new onset collagenous sprue and ETL is described. This case of collagenous sprue is an atypical CD3+, CD8-/+ intraepithelial T cell disorder and presumably a noninvasive component of the ETL.

\section{CASE PRESENTATION}

A 64-year-old man presented to the emergency room with $8 \mathrm{~h}$ of abdominal pain. Examination delineated an acute abdomen with maximum tenderness superior to the umbilicus. No mass, organomegaly or peripheral lymphadenopathy was noted. Radiological imaging verified viscus perforation with free air under the diaphragm and air-fluid levels of bowel obstruction. He relayed a 10 -month history of diarrhea, abdominal pain, anorexia and a $13.6 \mathrm{~kg}$ weight loss over the previous six months. Diarrhea was semiformed stools, six to seven per day. He was on Synthroid (Abbott Laboratories, Canada) $0.1 \mathrm{mg} /$ day for chronic hypothyroidism and had a remote episode of typhoid fever (1963). He had visited India for the five months before admission. His family history was remarkable for a sister with diabetes but there was no documentation of celiac disease or gastrointestinal illness.

${ }^{1}$ Calgary Laboratory Services, ${ }^{2}$ Department of Gastronterology, Peter Lougheed and Foothills Medical Centre, Calgary, Alberta

Correspondence and reprints: Dr Shaun Medlicott, Department of Laboratory Medicine and Calgary Laboratory Services, Peter Lougheed Centre,

3500-26 Street Northeast, Calgary, Alberta T1Y 6J4. Telephone 403-943-4907, fax 403-291-2931, e-mail shaun.medlicott@cls.ab.ca Received for publication January 2, 2004. Accepted March 192004 


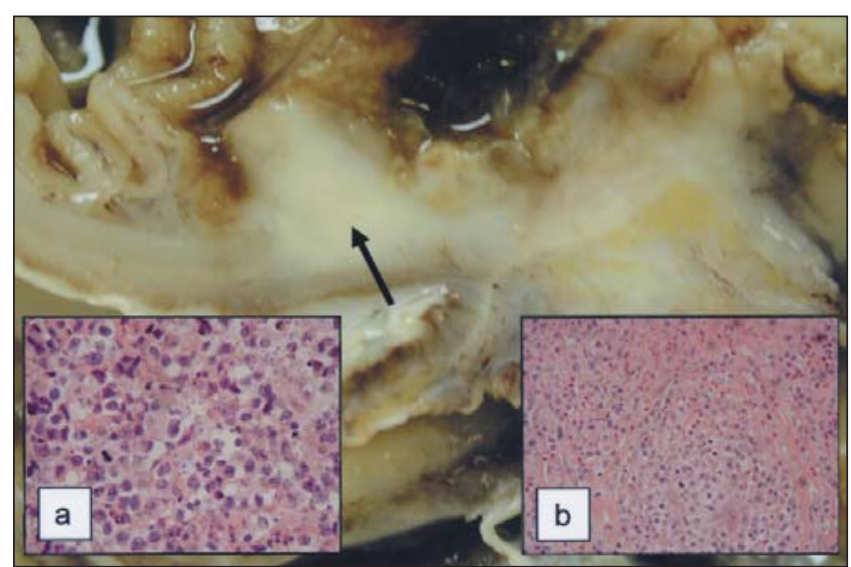

Figure 1) Obstructing lymphoma of jejunum effaces muscularis propria (arrow) and invades pericystic fat. Note intact valvulae adjacent tumour. (a) Neoplastic cells have abundant clear cytoplasm, large irregular nuclei and prominent apoptosis (hematoxylin and eosin stain, original magnification 400x). (b) Sclerosis and eosinophils are focally obvious (hematoxylin and eosin stain, original magnification 400x)

Admission serology revealed an hemoglobin of $147 \mathrm{~g} / \mathrm{L}$, low-normal mean corpuscular volume of $82 \mathrm{fL}$ (normal value $82 \mathrm{fL}$ to $100 \mathrm{fL}$ ) and mean corpuscular hemoglobin concentration of $324 \mathrm{~g} / \mathrm{L}$ (normal value $320 \mathrm{~g} / \mathrm{L}$ to $360 \mathrm{~g} / \mathrm{L}$ ). His white blood cell count was $6.9 \times 10^{9} / \mathrm{L}$ and platelets were normal at $376 \times 10^{9} /$ L. Serum glucose and liver studies were normal.

At laparotomy, stenosed mid-jejunum was adherent to the urinary bladder. A fibrinous exudate indicated perforation and associated mural induration was suspicious for neoplasm. No significant lymphadenopathy or organomegaly was noted.

A $29.8 \mathrm{~cm}$ segment of bowel with central serosal fibrinous exudates was received for pathological examination. Midaspect serosa had adherent rubbery tissue deep to an annular $5.3 \times 4.8 \times 0.9 \mathrm{~cm}$ indurated mucosal plaque that was centrally ulcerated (Figure 1). Small areas of flattened valvulae conniventes, the largest $2 \mathrm{~cm}$ in diameter, were separated from the plaque by intact mucosa. Rare soft mesenteric lymph nodes were evident.

Postoperative serology delineated a positive antiendomysial antibody titer of 1:20 (normal less than 1:2.5). Total iron binding capacity was low $(28 \mu \mathrm{mol} / \mathrm{L}$; normal values $40 \mu \mathrm{mol} / \mathrm{L}$ to $77 \mu \mathrm{mol} / \mathrm{L})$, vitamin $B_{12}$ was elevated at $1179 \mathrm{pmol} / \mathrm{L}$ (normal values $155 \mathrm{pmol} / \mathrm{L}$ to $800 \mathrm{pmol} / \mathrm{L}$ ) and his normal red cell folate levels were normal at $605 \mathrm{mmol} / \mathrm{L}$ (normal greater than 435). Hypoalbuminemia was noted at $23 \mathrm{~g} / \mathrm{L}$ (normal $33 \mathrm{~g} / \mathrm{L}$ to $48 \mathrm{~g} / \mathrm{L}$ ). Selective immunoglobulin (Ig) $\mathrm{M}$ deficiency of $0.28 \mathrm{~g} / \mathrm{L}$ (normal values $0.5 \mathrm{~g} / \mathrm{L}$ to $3 \mathrm{~g} / \mathrm{L}$ ) was present, and normal levels of IgG $(9.29 \mathrm{~g} / \mathrm{L}$; normal $6.8 \mathrm{~g} / \mathrm{L}$ to $18 \mathrm{~g} / \mathrm{L})$ and $\operatorname{IgA}(2.99 \mathrm{~g} / \mathrm{L}$; normal values $0.6 \mathrm{~g} / \mathrm{L}$ to $4.2 \mathrm{~g} / \mathrm{L}$ ) were detected.

The only extraintestinal manifestation of celiac disease was splenic atrophy, that was detected on an abdominal computed tomography scan. There was no accompanying red blood cell dysmorphism. Liver imaging was unremarkable and no retroperitoneal lymphadenopathy was noted.

A gluten-free diet was initiated in hospital. Ten months after surgery, he had regained lost weight and bowel movements had returned to normal due to strict adherence to the diet. No steroids or chemotherapy were administered.

\section{METHODS}

Histological assessment

Submitted bowel was fixed in 10\% formalin, processed, paraffin embedded, sectioned and stained with hemotoxylin and eosin. Some sections were stained with Masson's trichrome when superficial basement membranes of mucosa appeared thickened.

\section{Immunohistochemistry assessment}

Serial $4 \mu \mathrm{m}$ tissue sections were mounted on positively charged slides. The Ventana Iview Detection System (Ventana Medical Systems Inc, United States) employing biotinylated Ig anti-mouse and anti-rabbit as a secondary link, streptavidin-horseradish peroxidase as a third stage, and diaminobenzedine (Sigma, United States) as the chromogen was used. Slides were processed at $37^{\circ} \mathrm{C}$ for $16 \mathrm{~min}$ to $32 \mathrm{~min}$ on the Iview system, washed in rinsed water, counterstained with Gill's hematoxylin and then coverslipped.

Individual tests included: CD2 (Novo Castra, Vector Laboratory, Canada) of dilution 1:200, CD3 (Dako, Canada) 1:300, CD4 (Novo Castra, Vector Laboratory, Canada) 1:50, CD5 (Neomarker, Medicorp, Canada) 1:40, CD7 (Novo Castra, Vector Laboratory, Canada) 1:100, CD8 (Dako, Canada) 1:100, CD10 (RDI, United States) 1:100, CD15 (Ventana, United States), CD20 (Dako, Canada) 1:500, CD30 (Ventana, United States), CD43 (Novo Castra, Vector Laboratory, Canada) 1:100, Alk 1 (Dako, Canada) 1:500, bcl-2 (Ventana, United States), granzyme B (Citric) 1:25 and epithelial membrane antigen (Dako, Canada) 1:200. Ventana antibodies were prediluted by the manufacturer. Tests were run in parallel with positive control sections.

Assessment of collagenous sprue intraepithelial lymphocytosis was via the established French Celiac Disease Study Group protocol (3). Three authors (SACM, SL, TC) analyzed at least five adjacent increments of 100 epithelial cells on CD3- and CD8stained sections of collagenous sprue for IEL. An abnormal CD8 quantity (negative result) was defined as a 50\% reduction in CD8 staining cells compared with CD3 counts (3). Celiac sprue mucosa, from the same bowel resection, was assessed as a control.

\section{Epstein-Barr virus in situ hybridization}

Presence of Epstein-Barr virus was assessed using the ISH-B1 detection kit (Sigma, United States). Tissue slides were prepared by serial deparaffinization, enzyme digestion, endogenous peroxidase blocking then dehydration before denaturation and hybridization with $10 \mu \mathrm{L}$ to $20 \mu \mathrm{L}$ of appropriate oligo probes. Each slide was then treated with a drop of ExtraAvidin Peroxidase reagent (Dako, Canada) and subsequent Monoclonal Anti-Avidin Biotin Conjugate reagent (Dako, Canada). Slides were washed in rinsed water, counterstained with Gill's hematoxylin and coverslipped.

\section{Polymerase chain reaction analysis for gene rearrangements}

TCR- $\gamma$ assessment entailed two amplification reactions: $\gamma 11 / \gamma 101$ and $\gamma 12$; and $\gamma 11 / \gamma 101$ and $\gamma \mathrm{p} 12$, initiated by standard primers (7). Positive ranges were 75 to 100 base pairs (bp) for TCR- $\gamma 12$ and 80 to $120 \mathrm{bp}$ for $\gamma \mathrm{p} 12$.

TCR $-\beta$ testing included four reactions: $\beta \mathrm{V}$ with $\beta \mathrm{J} 1 ; \beta \mathrm{V}$ with $\beta \mathrm{J} 2$; $\beta \mathrm{J} 2$ with $\beta \mathrm{D} 1$; and $\beta \mathrm{J} 2$ with $\beta \mathrm{D} 2$, using standard primers (7). Positive tests were 55 to $100 \mathrm{bp}$.

Formalin-fixed paraffin-embedded bowel substrate was run for 40 cycles. 


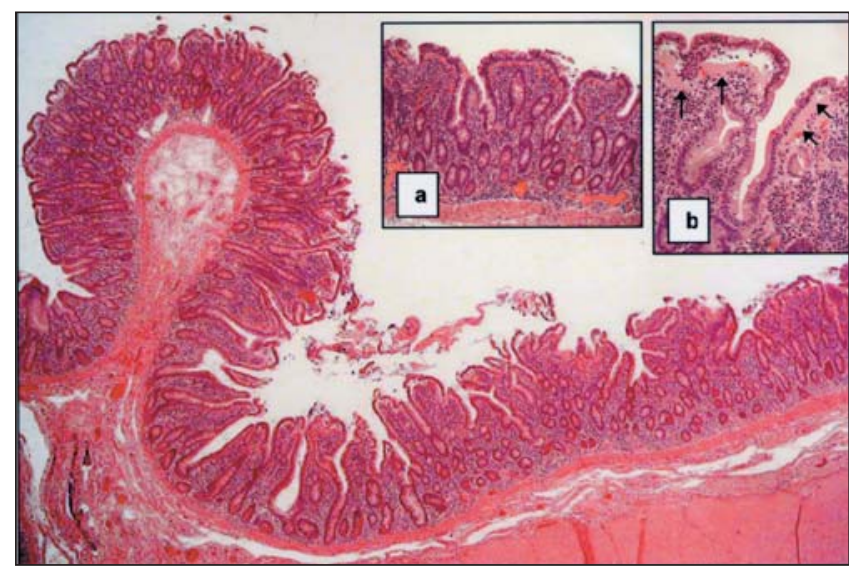

Figure 2) Scalloped mucosa of collagenous sprue (hematoxylin and eosin stain [HËE], original magnification 20x). (a) Typical celiac disease villous: crypt distortion and mucosal inflammation (HËE, original magnification 200x). (b) Superficial basement membrane prominence and intraepithelial lymphocytosis of collagenous sprue (HËE, original magnification $400 x$ )

\section{RESULTS}

\section{Histology}

Bowel mucosa had a prominent and confluent lamina propria lymphoplasmacytosis with abundant IELs. IELs of celiac disease mucosa were bland, small and readily exceeded 40 per 100 epithelial cells (a mean of 71.8 per 100 epithelial cells). Villous atrophy was near total in many histological sections and crypt hyperplasia was prominent.

The ulcerated plaque was a sheet of monomorphic discohesive cells. Cells had abundant, pale cytoplasm and their large vesicular nuclei had thick, angulated membranes. A prominent nucleolus was evident in the majority of nuclei. Mitotic activity and apoptotic bodies were frequent. These lymphoid cells focally had an angiocentric distribution. Eosinophils and occasional plasma cells were most discernable in areas of sclerosis. No hallmark or Reed-Sternberg cells were identified.

Florid collagenous sprue was most obvious in the largest focus of flattened mucosa (Figure 2). Focal superficial basement membrane thickening (greater than $10 \mu \mathrm{m}$ ) entrapped rare inflammatory cells and had patchy detachment of overlying surface epithelium.

\section{Immunohistochemistry}

The neoplasm was positive for CD2, CD3, CD5, CD7, CD43, $\mathrm{CD} 45 \mathrm{RO}$ and granzyme B. Rare anaplastic large cells were CD30+. Scant neoplastic cells were weakly positive for CD8. Lymphoma was CD4, CD10, CD20, CD15, Alk-1 and epithelial membrane antigen-negative.

IELs were $\mathrm{CD} 3+, \mathrm{CD} 8+$ in surface mucosa remote from the tumour. The IELs CD3:CD8 was 1.4:1. However, both CD3 and CD8+ IELs were less numerous in collagenous sprue (20.2\% and $27.9 \%$ reduction, respectively, versus celiac mucosa) (Figure 3). CD8 cells were preferentially reduced such that the collagenous sprue IEL CD3:CD8 was 2:1 (51\%) and interpreted as a CD3+, CD8- phenotype according to the French Celiac Disease Study Group protocol (3). Rare CD8 + cells had large, angulated nuclei, similar to the few weakly positive CD8 cells within the lymphoma (Figure 4).

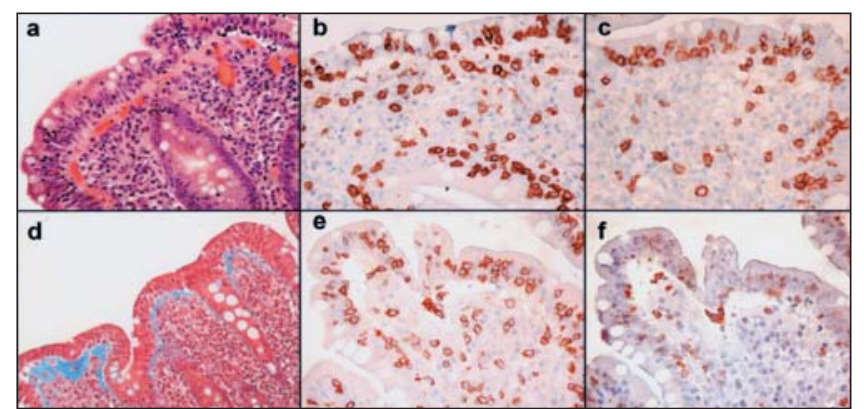

Figure 3) Celiac sprue (a) (hematoxylin and eosin stain, original magnification 400x) has a CD3 (b); CD8 (c) of 1.4:1. Collagenous sprue (d), Masson's trichrome, original magnification 400x) has a CD3 (e); CD8 (f) of 2:1. Both CD3 and CD8 intraepithelial lymphocytes are reduced in collagenous sprue, especially CD8 cells

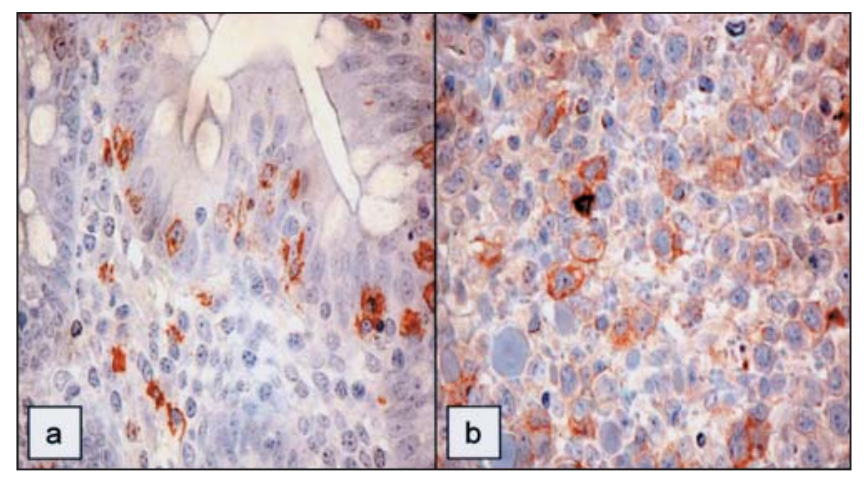

Figure 4) Comparison of weakly staining CD8+ intraepithelial lymphocytes of collagenous sprue (a) to rare atypical weakly CD8+ lymphocytes of the enteropathy-type $T$ cell lymphoma (b)

\section{Gene rearrangement}

The lymphoma had TCR $-\gamma$ and $-\beta$ monoclonal rearrangements. Both collagenous and celiac sprue mucosa lacked definite clonal rearrangements.

\section{In situ hybridization}

The lymphoma was negative for Epstein-Barr virus.

\section{DISCUSSION}

Celiac disease is a common illness with a prevalence of 1:150 to $1: 350$ in North America and Europe (8-11). The disease may be polygenic, with different genes parlaying gluten sensitivity in the varied patient populations $(12,13)$. However, a specific HLA-DQ2 haplotype is seen in 95\% of subjects $(12,14)$. Classic presentations include fatigue, anorexia, diarrhea, abdominal pain, dyspepsia and iron/folic acid deficiencies, but many patients are asymptomatic.

The histological diagnosis of celiac disease is a triad of lamina propria lymphoplasmacytosis, villous atrophy/crypt hyperplasia and an intraepithelial lymphocytosis. Celiac sprue has an abundance of bland intraepithelial $\mathrm{T}$ cells primarily expressing CD3, CD8 and surface $\alpha \beta T C R$ (1). Smaller populations of IEL are CD4-, CD8- and surface $\gamma \delta \mathrm{TCR}+$, and there is a rare CD56+ cell type (1). The CD4-, CD8- lymphocyte population may double in celiac disease compared with normal bowel (15\% to $30 \%)$ and most ETLs are presumed to originate from this IEL lineage $(1,15)$. 
Refractory sprue is defined as a lack of clinical response to six months of a gluten-free diet $(12,16)$. The morphology of refractory disease may be identical to that of precursor celiac sprue but atypical IEL histology has been described (17). Ulcerative jejunitis, mesenteric lymph node cavitation and collagenous sprue are common histological variants that may account for $66 \%$ of all cases of refractory sprue $(1,3)$. When presenting in combination, $79 \%$ of refractory sprue subtypes will be monoclonal $\mathrm{T}$ cell proliferations with a poor prognosis (3). Refractory sprue and ulcerative jejunitis are now classified as cryptic ETL, due to their frequent CD3+, CD8- phenotype and monoclonal TCR gene rearrangements $(1-3,5,18)$. However, whether isolated collagenous sprue is a monoclonal disorder remains controversial $(3,4)$.

Collagenous sprue encompasses celiac disease histology but it is distinguished by thickened mucosal superficial basement membranes (greater than $10 \mu \mathrm{m}$ ) and detachment of overlying epithelium $(3,19)$. Cellier et al (3) studied seven collagenous sprue patients, with one developing ETL four years subsequently. This patient had an abnormal CD3+, CD8- IEL and gene rearrangement was not performed (3). In contrast, Daum et al (4) indicated that their two uncomplicated collagenous sprue patients had a majority of IEL coexpressing CD3, CD8 and no TCR $-\gamma$ rearrangements. Our patient had an abnormal CD3+, CD8-/+ intraepithelial lymphocytosis. Because the rare CD8+ cells in his collagenous sprue surface epithelium were atypically large with irregular nuclear membranes, similar to weakly staining cells in the lymphoma proper, we believe that collagenous sprue may represent an intraepithelial lymphoproliferative disorder. To our knowledge, this is original reporting of de novo ETL and collagenous sprue as synchronous lesions.

\section{REFERENCES}

1. Bagdi E, Diss T, Munson P, Isaacson PG. Mucosal intraepithelial lymphocytes in enteropathy-associated T-cell lymphoma, ulcerative jejunitis and refractory celiac disease consititute a neoplastic population. Blood 1999;94:260-4.

2. Du M-Q, Isaacson PG. First steps in unraveling the genotype of enteropathy-type T-cell lymphoma. Am J Pathol 2002;161:1527-9.

3. Cellier C, Delabesse E, Helmer C, et al. Refractory sprue, coeliac disease and enteropathy-associated T-cell lymphoma. Lancet 2000;356:203-8.

4. Daum S, Hummel M, Ulirich R, et al. Frequency of clonal intraepithelial T lymphocyte proliferations in enteropathy-type intestinal T cell lymphoma, celiac disease and refractory sprue. Gut 2001;49:804-9.

5. Ashton-Key M, Diss TC, Pan L, Du MQ, Isaacson PG. Molecular analysis of T-cell clonality in ulcerative jejunitis and enteropathyassociated T-cell lymphoma. Am J Pathol 1997;151:493-8.

6. Freeman HJ. Collagenous sprue associated with an extensive T-cell lymphoma. J Clin Gastroenterol 2003;36:144-6.

7. Abdel-Reheim F, Edwards E, Arber DA. Utility of a rapid polymerase chain reaction panel for the detection of molecular changes in B-cell lymphoma. Arch Pathol Lab Med 1996;120:357-63.

8. Catassi C, Fabiani E, Ratsch IM, et al. The celiac iceberg in Italy. A multicentre antigliadin antibodies screening for celiac disease in school-age subjects. Acta Paediatr Suppl 1996;412:29-35.

9. Not H, Horvath K, Hill ID, et al. Celiac disease risk in the USA: High prevalence of antiendomysium antibodies in healthy blood donors. Scand J Gastroenterol 1998;33:494-8.

10. Weile I, Grodzinsky E, Skogh T, Jordal R, Cavell B, Krasilnikoff PA. High prevalence rates of adult silent celiac disease, as seen in Sweden, must be expected in Denmark. APMIS 2001;109:745-50.

11. Farrell RJ, Kelly CP. Diagnosis of celiac sprue. Am J Gastroenterol 2001;96:3237-46.
Collagenous sprue and ETL classically have a metachronous relationship with an interval of one to four years separating established diagnoses $(3,6)$. Our patient had 10 months of symptoms before the diagnostic segmental resection. Such a period would be significant for diminishing the published interval between disease onsets, if these processes are truly independent. Alternatively, we believe the processes arose synchronously, representing noninvasive and invasive elements of one lymphoproliferative disorder. Alleviation of symptoms in the absence of steroid therapy may provide additional credence that the collagenous sprue segment was an atypical neoplastic process.

Our patient's ETL was positive for CD2, CD3 and CD7. Rare atypical CD8 + cells were evident in our patient's collagenous sprue surface epithelium and the ETL. Hypothetically, these atypical CD8+ cells may represent clonal evolution or aberrant staining of neoplastic lymphocytes. A CD5+ phenotype in this case of ETL is unusual but has been previously described $(20,21)$. Such CD5 positivity does not obviously alter prognosis (21).

\section{CONCLUSION}

A classic example of jejunal ETL prompted investigation for cryptic celiac disease. Diagnoses of celiac and collagenous sprue were validated clinically and histologically respectively. IEL of collagenous sprue had an atypical CD3+, CD8-/+ phenotype; an aberrance correlating with neoplasia. The rare CD8+ cells in collagenous sprue were histologically atypical, resembling those CD8+ cells in the ETL. As such, this case portends that collagenous sprue can be a noninvasive element of an ETL.

12. Jennings JSR, Howdle PD. Celiac disease. Gastroenterology 2001;17:118-26.

13. Kagnoff MF. Celiac disease pathogenesis: The plot thickens. Gastroenterology 2002;123:939-43.

14. Houlston RS, Tomlinson IPM, Ford D, et al. Linkage analysis of candidate regions for celiac disease genes. Hum Mol Genet 1997;6:1335-9.

15. Spencer J, Isaacson PG, Diss TC, MacDonald TT. Expression of disufide-linked and Non-disulfide-linked forms of the T-cell receptor $\alpha / \delta$ heterodimer in human intestinal intraepithelial lymphocytes. Eur J Immunol 1989;19:1335-8.

16. Trier JS, Falchuk Z, Carey M, Schreiber D. Coeliac sprue and refractory sprue. Gastroenterology 1978;75:307-16.

17. Riddell RH, Petras RE, Williams GT, Sobin LH. Lymphoproliferative disorders of the intestine. In: Rosai J, ed. Atlas of Tumor Pathology: Tumors of the Intestines. Fascicle 32. 3rd edn. Washington: Armed Forces Institute of Pathology, 2002:417-21.

18. Murray A, Cuevas EC, Jones DB, Wright DH. Study of the immunohistochem- istry and T cell clonality of enteropathyassociated T-cell lymphoma. Am J Pathol 1995;146:509-19.

19. Robert ME, Ament ME, Weinstein WM. The histologic spectrum and clinical outcome of refractory and unclassified sprue. Am J Surg Pathol 2000;24:676-87.

20. Arnulf B, Copie-Bergman C, Delfau-Larue MH, et al. Nonhepatosplenic gammadelta T-cell lymphoma: A subset of cytotoxic lymphomas with mucosal or skin localization. Blood 1998;91:1723-31.

21. Mathus-Vliegen EMH, Van Halteren H, Tytgat GNJ. Malignant lymphoma in celiac disease: Various manifestations with distinct symptomatology and prognosis? J Intern Med 1994;236:43-9. 


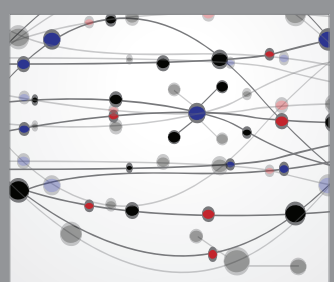

The Scientific World Journal
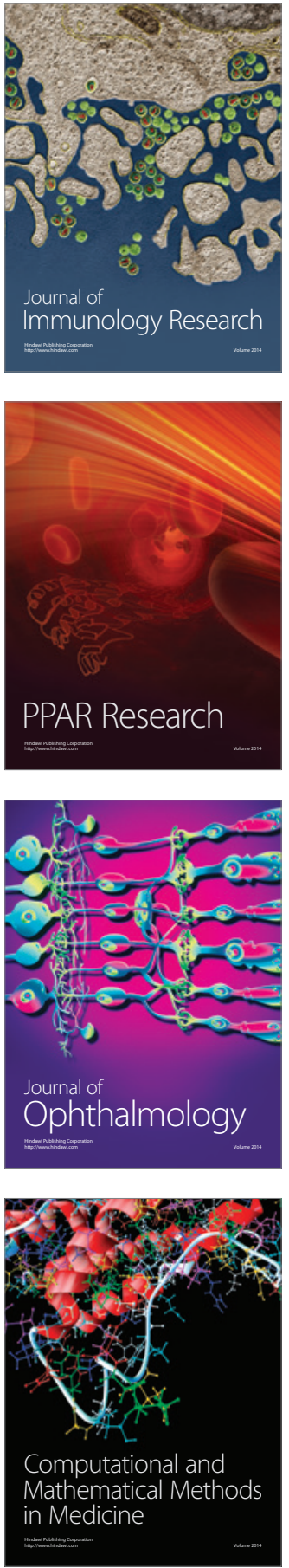

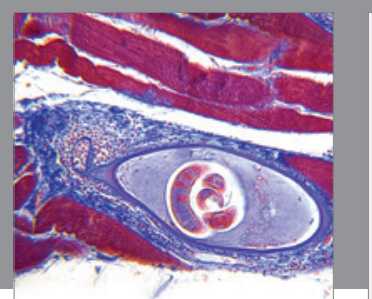

Gastroenterology Research and Practice

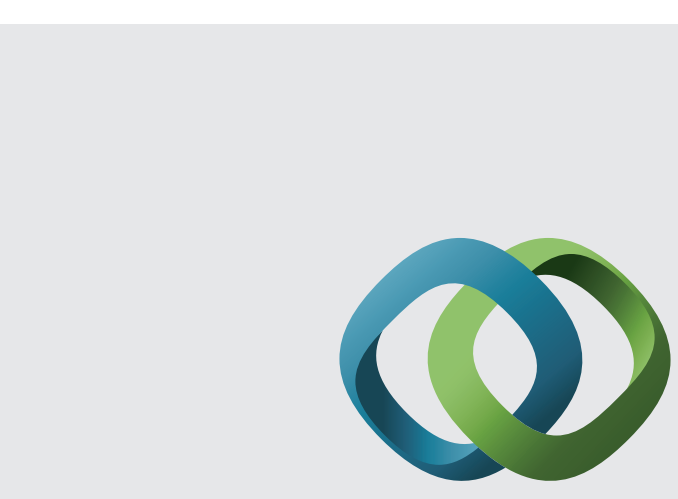

\section{Hindawi}

Submit your manuscripts at

http://www.hindawi.com
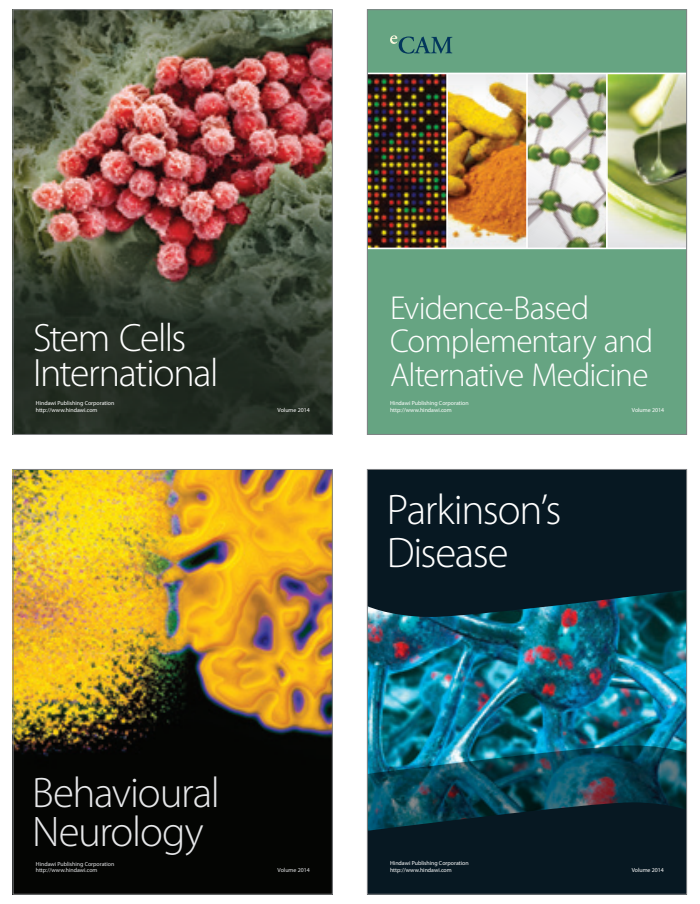
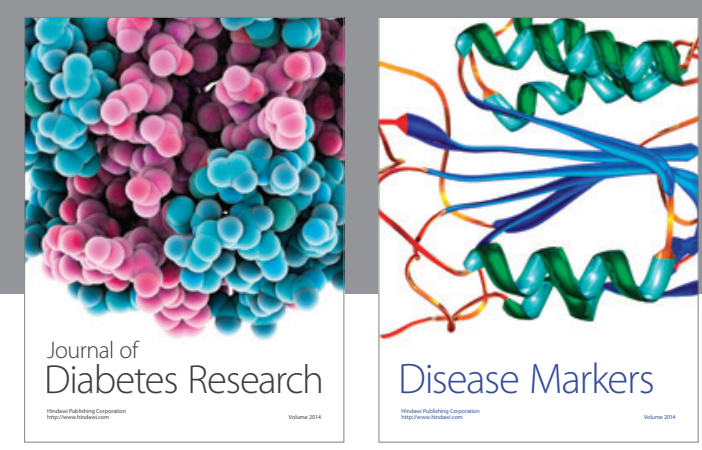

Disease Markers
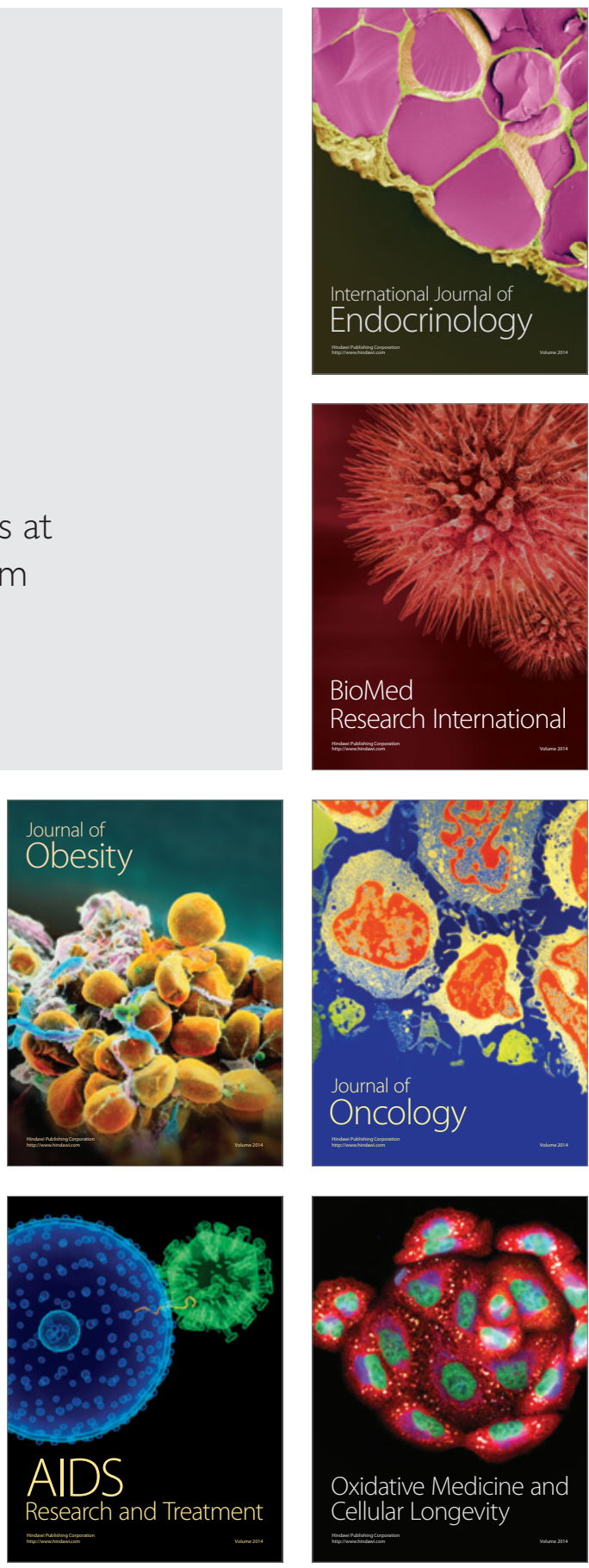